\title{
Hygiene practices in abattoir and slaughter slab, determinants and assessment of abattoir and slaughter slab facilities in Abakaliki, Ebonyi State South-East Nigeria
}

\author{
Adaoha Pearl Agu ${ }^{1,2,3}$, Cosmas Kenan Onah², Chukwuma David Umeokonkwo ${ }^{2}$, \\ Richard Chukwuka Nnabu ${ }^{2,4}$, Alfred Friday Igwe Una ${ }^{1,2}$
}

1. Department of Community Medicine, Ebonyi State University Abakaliki.

2. Department of Community Medicine, Alex Ekwueme Federal University Teaching Hospital Abakaliki (AE-FUTHA), Ebonyi State.

3. African Institute for Health Policy and Health Systems, Ebonyi State University Abakaliki.

4. Government House Clinic, Government House Abakaliki Ebonyi State.

\section{Co-authors' emails:}

Adaoha Pearl Agu: pearlagu@yahoo.co.uk; Cosmas Kenan Onah: onahcosyo@gmail.com; Chukwuma David Umeokonkwo: chukwumau@gmail.com; Richard Chukwuka Nnabu: nnaburich@gmail.com; Alfred Friday Igwe Una: alfreduna@yahoo.com

\begin{abstract}
Background: Workers in slaughterhouses engaging in unhygienic practices create conducive environments for zoonoses and meat contamination. Knowledge of hygiene practices and their determinants provides evidence for the design of targeted interventions.

Objectives: We investigated knowledge and determinants of hygiene practices among workers in slaughterhouses and assessed slaughterhouse facilities in Abakaliki.

Methods: Workers in the Central Meat Market abattoir and Slaughter slab Abakaliki were interviewed in a cross-sectional quantitative study to ascertain their knowledge and hygiene practices while abattoir facilities were assessed using a checklist. Associations were analysed with Chi-square while predictors were determined using binary logistic model.

Results: We interviewed 188 workers $75.5 \%$ and $85.6 \%$ of whom had good knowledge and good hygiene practices respectively. However, hand-washing before and after handling meat (44.1\%), cleaning work surfaces with soap and water (45.2\%) and sanitary disposal of waste $(6.9 \%)$ were suboptimal. Knowledge of good hygiene practice was a predictor of good hygiene practice (AOR: 4.6, 95\% CI: 2.0-11.3, $\mathrm{p}=0.001$ ). Well water and borehole were present in both slaughterhouses and cold rooms were available in Central Meat market abattoir.

Conclusions: The level of good knowledge was high and this was a determinant of good hygienic practices. Training on hygiene practices is recommended to prevent meat contamination and zoonoses.

Keywords: Knowledge, Hygiene Practices, Abattoir, Slaughter slab, Determinants, Ebonyi, Nigeria.

DOI: https://dx.doi.org/10.4314/ahs.v21i4.50

Cite as: Agu AP, Onab CK, Umeokonkwo CD, Nnabu RC, Una AFI. Hygiene practices in abattoir and slanghter slab, determinants and assessment of abattoir and slaughter slab facilities in Abakaliki, Ebonyi State South-East Nigeria. Afri Health Sci. 2021;21(4):1914-23. bttps:/ / dx.doi.org/10.4314/ahs.v21i4.50
\end{abstract}

\section{Introduction}

An issue of great interest and growing concern is the spread of infectious diseases that emerge or re-emerge

\section{Corresponding author: \\ Cosmas Kenan Onah \\ Department of Community Medicine, Alex Ekwueme Federal University Teaching Hospital Abakaliki, Ebonyi State Nigeria. Phone numbers: +2348063581170; +2348155956885 Email: onahcosyo@gmail.com}

from the interfaces between animals and humans and the ecosystems in which they live. Emerging and existing infectious diseases at the animal-human-ecosystem interface have been of growing concern because of their epidemic and endemic potential as well as their adverse socioeconomic consequences ${ }^{1}$. Key examples are zoonoses and foodborne diseases of animal origin which are of public health and animal health importance. Prevention of these diseases by controlling hazards in meat production processes and improving food safety has been recognized as an effective strategy ${ }^{2,3}$. 
Hazard analysis control points (HACCP) systems which prevent and reduce food safety hazards through critical control points $(\mathrm{CCP})^{5}$, as well as good hygiene practices, are both parts of an effective food safety management system ${ }^{6}$. Despite the importance of optimum levels of food safety (meat safety) in abattoirs, reports have shown it to be poor in some abattoirs in Nigeria, with interventions needed in the food safety plan $^{6,7}$.

Workers in abattoirs who engage in unhygienic practices, create a conducive environment for zoonoses among the workers and contamination of the meat for sale $^{8}$. Unfortunately, the microbial profile of meat in abattoirs and butchery shops in sub-saharan countries including Nigeria, is higher than standards set by World Health Organization (WHO) $)^{9,10}$ and there have been occurrences of zoonoses among abattoir workers and in cattle in abattoirs across Nigeria ${ }^{11-13}$. Studies in Nigeria have also reported substandard facilities, unsanitary environments and poor hygienic practices in abattoirs and slaughterhouses ${ }^{14-20}$ even though abattoir sanitation is an essential component of The National Environmental Sanitation Policy of Nigeria ${ }^{21}$.

The focus of the few published research on abattoirs in Ebonyi State has been on isolation of micro-organisms in the environment ${ }^{22}$, antimicrobial resistance to antibiotics $^{23,24}$ and isolation of helminths in ruminants ${ }^{25}$. A study $^{23}$ on the assessment of bacteria effluent qualities reported the presence of antibiotic- resistant bacteria in untreated abattoir wastewater at the abattoir in the Central Meat Market, Abakaliki but an assessment of the facilities was outside its scope. A similar study ${ }^{24}$ on the antibiotic susceptibility pattern of Salmonella and Pseudomonas species isolated from the effluents from the Central Meat Market abattoir and the slaughter slab in Abakaliki described the bacterial profile and multidrug-resistant traits of the species found. In contrast, there is much less information on hygienic practices of the workers in these slaughterhouses in Abakaliki.

The purpose of this study was to investigate the knowledge and determinants of hygiene practices among workers in abattoir and slaughter slab in Abakaliki, Ebonyi State and assess the facilities. The findings could serve as a baseline in the design of interventions to protect the meat from contamination and the workers from zoonoses.

\section{Methods}

\section{Study Area and Design}

We conducted a total population cross-sectional quantitative study among workers in the abattoir and slaughter slab in Abakaliki city which spans parts of Abakaliki and Ebonyi Local Government Areas (LGAs) of Ebonyi State, South East Nigeria. Ebonyi State is one of the 36 states of the Federal Republic of Nigeria with its capital as Abakaliki. Abakaliki had a projected population of 172,176 in $2011^{26}$. The inhabitants are mostly farmers, traders and civil servants. The temperature in Abakaliki varies from $65 \circ \mathrm{F}$ to $89 \circ \mathrm{F}^{27}$. The sliding 31-day rainfall is at least 0.5 inches in the rainy season (February to November) and most rain falls during the 31 days centered around September 22 with an average total accumulation of 8.9 inches $^{27}$.
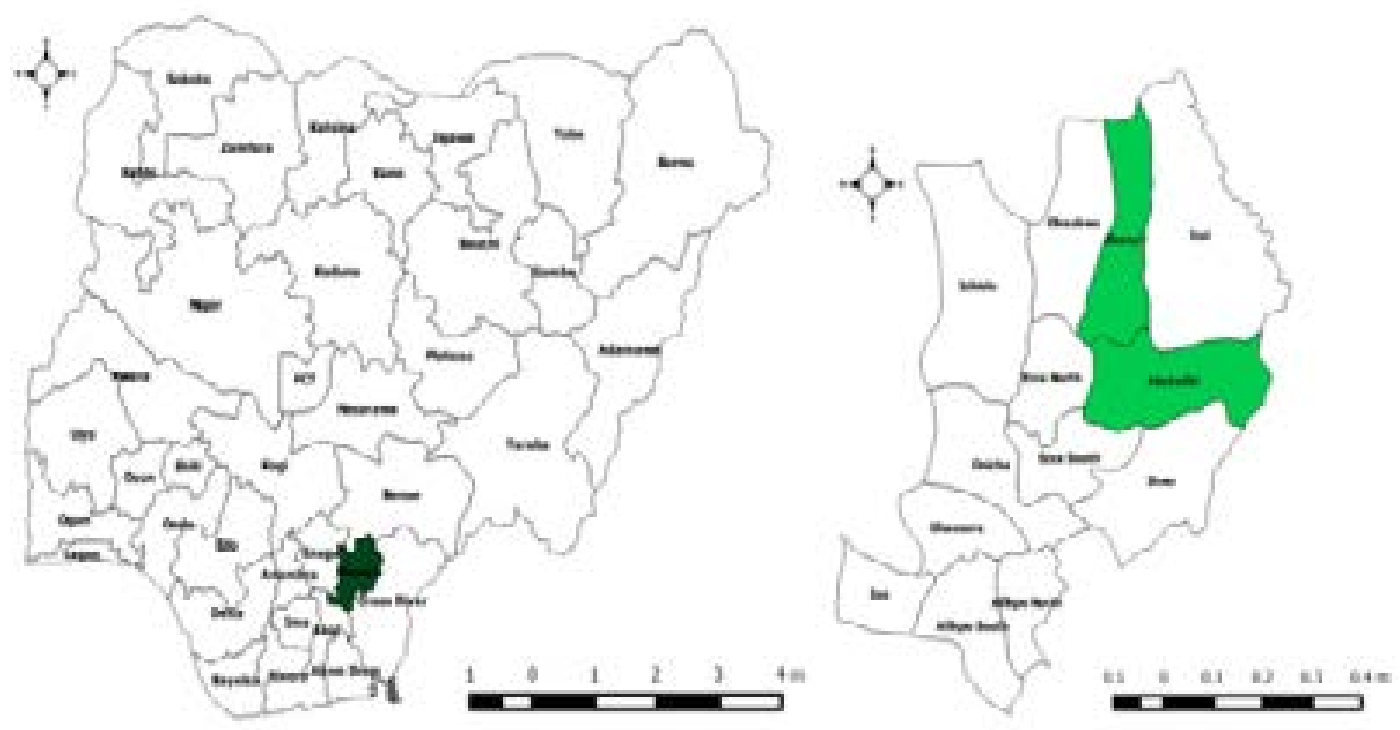

Figure 1: Maps of Nigeria showing Ebonyi State (left) and Ebonyi State (right) showing the LGAs where the study sites are located (in green) 
The study sites were the major meat processing points in Abakaliki city located in the abattoir in the Central Meat Market, Abakpa market (in Ebonyi LGA) and the Slaughter slab on Ogoja road (in Abakaliki LGA). The animals slaughtered in Central Meat Market abattoir are cow, sheep and occasionally goats (180 to 450 animals monthly) while only cows (180 to 360 monthly) are slaughtered at the Slaughter slab. The survey was on the abattoir workers' knowledge and practice of good hygiene and sanitation. All the workers in the selected abattoirs who gave informed consent were eligible for study which took place during their monthly meetings in February and March 2016. Workers who were absent during the February meeting were reached in their workplace in March. People who sell food and other items in and around the premises were excluded from the study.

\section{Data Collection and Management}

Data were collected using pre-tested interviewer-administered questionnaires. The questionnaire was designed by the researchers using published related research ${ }^{28,29}$ and reviewed by experts in public health, microbiology and sociology disciplines for content validity. A pre-test of the questionnaire was carried out on ten workers in a nearby town - Ezzamgbo in Ebonyi State and a few of the questions were modified to improve understanding. A double translation of the questionnaire was done between English and the local dialects of the Igbo language. Five trained research assistants with tertiary education in medical and para-medical sciences administered the questionnaire in the local dialect of the Igbo language. The questionnaire had sections on socio-demographic and work characteristics, knowledge, attitude and practices of good hygiene and sanitation. We assessed the availability of the abattoir and slaughter slab facilities using a checklist adapted from the Policy guidelines on market and abattoir sanitation developed by the Nigerian Federal Ministry of Environment ${ }^{21}$.

\section{Statistical Analysis}

Data analysis was carried out with IBM SPSS Statistics version 20. Knowledge questions were scored zero for incorrect and one for accurate response; total overall possible knowledge score was 23 . Scores of 11.5 marks and above were graded as good knowledge while those below were graded as poor. Similar to knowledge, practice questions were also scored zero for incorrect and one for an accurate response; scores of 8.5 marks up to a maximum of possible 17 were graded as good practice while those below 8.5 were categorized as poor. The modified Bloom's cut-off was used to categorize these variables ${ }^{30}$. Statistically significant relationships of independent variables with knowledge and practice were determined at $\mathrm{p}<0.05$ and a cut-off of $\mathrm{p}=0.2$ was the criteria for inclusion of independent variables into binary logistic model for determination of predictors of knowledge and practice.

\section{Results}

All the workers (188) in the abattoir and slaughter slab were interviewed and all responded adequately to the questions, giving a response rate of $100 \%$. One hundred and eighteen $(62.8 \%)$ of the respondents were -workers in the Central Meat Market abattoir while 70 $(37.2 \%)$ were in Slaughter slab. The majority of the abattoir workers were males 136 (72.3\%) and Christians $168(89.4 \%)$ between the ages of 21 and 40 years 137 (72.9\%). The abattoir workers were mostly retailers 93 (49.5\%) and butchers $83(44.1 \%)$ and many of them had received training on abattoir work $149(79.3 \%)$ which was majorly provided by their employers $121(81.2 \%)$. 
Table 1. PPE^ usage, reported availability of abattoir facilities and knowledge of good hygiene practices

\begin{tabular}{|c|c|}
\hline Variables & $\begin{array}{l}\text { Frequency } \\
(\%)\end{array}$ \\
\hline Used any PPE & $161(85.6)$ \\
\hline \multicolumn{2}{|l|}{ Frequency of use of PPE } \\
\hline Always & $119(73.9)$ \\
\hline Sometimes & $41(25.5)$ \\
\hline Rarely & $1(0.6)$ \\
\hline \multicolumn{2}{|l|}{ Provider of PPE used } \\
\hline Self & $126(78.3)$ \\
\hline Employer & $32(19.9)$ \\
\hline Environmental health officer & $3(1.9)$ \\
\hline \multicolumn{2}{|l|}{ Type of PPE used } \\
\hline Apron & $154(81.9)$ \\
\hline Boot & $13(6.9)$ \\
\hline Hand glove & $13(6.9)$ \\
\hline Face mask & $4(2.1)$ \\
\hline Goggles & $2(1.1)$ \\
\hline Cap & $2(1.1)$ \\
\hline \multicolumn{2}{|l|}{ Method of abattoir waste disposal known } \\
\hline Open dumping & $143(76.1)$ \\
\hline Burning & $13(6.9)$ \\
\hline Land filling & $21(11.2)$ \\
\hline Do not know & $11(5.9)$ \\
\hline \multicolumn{2}{|c|}{ Food and environmental safety measures known* } \\
\hline Proper waste disposal & $151(80.3)$ \\
\hline Proper storage of leftover meat & $135(71.8)$ \\
\hline Regular hand-washing & $134(71.3)$ \\
\hline Wearing PPE & $131(69.7)$ \\
\hline Washing hand after going to toilet & $113(60.1)$ \\
\hline Wiping work surface with soap \& water & $82(43.6)$ \\
\hline \multicolumn{2}{|c|}{ Benefits of working in safe environment known* } \\
\hline Enhanced good health & $155(82.4)$ \\
\hline Avoidance of disease transmission & $130(69.1)$ \\
\hline Avoidance of injuries & $104(55.3)$ \\
\hline Enhanced efficiency & $63(33.5)$ \\
\hline \multicolumn{2}{|l|}{ Insufficiency of cleaning materials } \\
\hline Brooms & $37(61.7$ \\
\hline Forks/shovel & $12(20.0)$ \\
\hline Soap & $11(18.3)$ \\
\hline \multicolumn{2}{|l|}{ Source of water in abattoir } \\
\hline Borehole & $109(58.0)$ \\
\hline Well & $74(39.4)$ \\
\hline Tap & $5(2.7)$ \\
\hline \multicolumn{2}{|c|}{$\begin{array}{l}\text { Government and health agencies are actively being involved in } \\
\text { ensuring good hygiene practice in abattoir }\end{array}$} \\
\hline Yes & $132(70.2)$ \\
\hline No & $56(29.8)$ \\
\hline \multicolumn{2}{|c|}{ Knowledge of good hygiene practices and PPE } \\
\hline Good & $142(75.5)$ \\
\hline Poor & $46(24.5)$ \\
\hline
\end{tabular}

Table 1 shows that majority 161 (85.6\%) of the abattoir workers used personal protective equipment (PPE) and apron is the most commonly used. Over $70 \%$ of them used these PPE regularly of which $78 \%$ of them are provided by the workers themselves. Over $70 \%$ of the workers knew proper waste disposal, proper storage of leftover meat and regular hand-washing as food safety and environment safety measures while the least known measure was wiping of surface with soap and water, known only to $43.6 \%$. About $70 \%$ agreed that government and health agencies are actively involved in making sure that proper hygiene is observed in the abattoir. Generally, the abattoir workers had good knowledge level of good hygiene practices $(75.5 \%)$. 
Table 2. Reported hygiene practices of abattoir workers

\begin{tabular}{|c|c|}
\hline Variable & Frequency $(\%)$ \\
\hline \multicolumn{2}{|l|}{ Method of abattoir waste disposal: } \\
\hline Open dumping & $157(83.5)$ \\
\hline Burning & $17(9.0)$ \\
\hline Land filling & $10(5.3)$ \\
\hline Burying & $3(1.6)$ \\
\hline Others & $1(0.5)$ \\
\hline \multicolumn{2}{|l|}{ Frequency of cleaning work surface } \\
\hline Daily & $153(81.4)$ \\
\hline After every sale & $25(13.3)$ \\
\hline Weekly & $8(4.3)$ \\
\hline Monthly & $1(0.5)$ \\
\hline Occasionally & $1(0.5)$ \\
\hline \multicolumn{2}{|l|}{ Material used to clean work surface: } \\
\hline Water only & $103(54.8)$ \\
\hline Soap and water & $85(45.2)$ \\
\hline \multicolumn{2}{|l|}{ Frequency of cleaning abattoir lairage } \\
\hline Daily & $137(72.9)$ \\
\hline Weekly & $9(4.8)$ \\
\hline Monthly & $3(1.6)$ \\
\hline Don't know & $37(20.7)$ \\
\hline \multicolumn{2}{|l|}{ Where meat is stored } \\
\hline Cold room & $94(50.0)$ \\
\hline Freezer & $41(21.8)$ \\
\hline Refrigerator & $39(20.7)$ \\
\hline None & $8(4.3)$ \\
\hline Room temperature & $6(3.2)$ \\
\hline \multicolumn{2}{|l|}{ Method of preserving leftover meat: } \\
\hline Freezing & $99(52.7)$ \\
\hline Refrigeration & $79(42.0)$ \\
\hline None & $13(6.9)$ \\
\hline Drying & $11(5.9)$ \\
\hline Smoking & $10(5.3)$ \\
\hline Salting & $1(0.5)$ \\
\hline \multicolumn{2}{|l|}{ Food safety measures practised during work: } \\
\hline Disposing of spoilt meat & $183(97.3)$ \\
\hline Avoiding work when suffering from diarrhoea & $170(90.4)$ \\
\hline Avoiding work while having boils & $167(88.8)$ \\
\hline Avoiding work when suffering from flu & $161(81.5)$ \\
\hline Washing hands after using the bathroom & $135(71.8)$ \\
\hline Avoiding keeping long nails & $106(56.4)$ \\
\hline Wearing PPE & $102(54.3)$ \\
\hline Washing hands before and after handling meat & $83(44.1)$ \\
\hline \multicolumn{2}{|l|}{ Abattoir workers hygiene practice } \\
\hline Good & $161(85.6)$ \\
\hline Poor & $27(14.4)$ \\
\hline
\end{tabular}

Table 2 shows that open dumping is the commonest waste disposal method reported by the workers (83.5\%), while burning, land filling and burying were reported by $9.0 \%, 5.3 \%$ and $1.6 \%$ respectively. Majority, $153(81.4 \%)$, of the abattoir workers clean their work surfaces daily and less than half $(45.2 \%)$ of the respondents used soap and water in the cleaning process. Half of them store meat in cold rooms and a little over $20 \%$ use freezers and refrigerators for that purpose. Eight (4.3\%) do not use any storage system while $6(3.2 \%)$ leave the meat at room temperature. Similarly, $99(52.7 \%)$ store left-over meat in deep freezers and 79
$(42.0 \%)$ use refrigerators for storage. Eleven $(5.9 \%)$ and $10(5.3 \%)$ dry or smoke such left overs respectively. The commonest food safety measures practiced by the abattoir workers while at work include disposal of spoilt meat $183(97.3 \%)$ and avoiding work if they had diarrhea $170(90.4 \%)$. Over $80 \%$ avoid work if they had boil or suffered flu respectively. Hand hygiene after using the bathroom was practiced by 135 (71.8\%). Washing hands before and after handling meat was not a common practice among them as only 83 (44.1\%) observe such practice. However, overall good composite practice was seen in majority $(85.6 \%)$ of the respondents. 
Table 3. Relationship of socio-demographic and other variables with knowledge of good hygiene practice

\begin{tabular}{|c|c|c|c|c|c|}
\hline \multirow[t]{2}{*}{ Variable } & \multicolumn{5}{|c|}{$\begin{array}{c}\text { Knowledge of good hygiene practice } \\
n=188 \\
\mathrm{~N}(\%) \\
\end{array}$} \\
\hline & $\begin{array}{l}\begin{array}{l}\text { Good } \\
(n=142)\end{array} \\
(n-14\end{array}$ & $\begin{array}{l}\text { Poor } \\
(n=46)\end{array}$ & Total & $\chi^{2}$ & p-value \\
\hline \multicolumn{6}{|l|}{ Age group (years) } \\
\hline$\leq 30$ years & $82(57.7)$ & $23(50.0)$ & 105 & 0.846 & 0.358 \\
\hline$>30$ years & $60(42.3)$ & $23(50.0)$ & 83 & & \\
\hline \multicolumn{6}{|l|}{ Sex } \\
\hline Male & $108(76.1)$ & $28(60.9)$ & 136 & 4.005 & 0.045 \\
\hline Female & $34(23.9)$ & $18(39.1)$ & 52 & & \\
\hline \multicolumn{6}{|l|}{ Marital status } \\
\hline Married & $70(49.3)$ & $27(58.7)$ & 97 & 1.229 & 0.268 \\
\hline Not married & $72(50.7)$ & $19(41.3)$ & 91 & & \\
\hline \multicolumn{6}{|l|}{ Religion } \\
\hline Christianity & $128(90.1)$ & $40(87.0)$ & 168 & 0.371 & 0.543 \\
\hline Islam & $14(9.9)$ & $6(13.0)$ & 20 & & \\
\hline \multicolumn{6}{|l|}{ Level of education } \\
\hline$<$ Secondary education & $54(38.0)$ & $17(37.0)$ & 71 & 0.017 & 0.896 \\
\hline$\geq$ Secondary education & $88(62.0)$ & $29(63.0)$ & 117 & & \\
\hline \multicolumn{6}{|l|}{ Work experience } \\
\hline$\leq 5$ years & $76(53.5)$ & $26(56.5)$ & 102 & 0.126 & 0.723 \\
\hline$>5$ years & $66(46.5)$ & $20(43.5)$ & 86 & & \\
\hline \multicolumn{6}{|l|}{ Category of worker } \\
\hline Retailer & $80(56.3)$ & $13(28.3)$ & 93 & 10.957 & $0.001 *$ \\
\hline Butchers and others & $62(43.7)$ & $33(71.7)$ & 95 & & \\
\hline \multicolumn{6}{|c|}{$\begin{array}{l}\text { Previous training on abattoir } \\
\text { work }\end{array}$} \\
\hline Yes & $119(83.8)$ & $30(65.2)$ & 139 & 7.300 & $0.007 *$ \\
\hline No & $23(16.2)$ & $16(34.8)$ & 49 & & \\
\hline
\end{tabular}

As shown in Table 3, a greater proportion $(57.0 \%)$ of abattoir workers who had good knowledge of abattoir hygiene practices were aged less than 30 years. Being a meat product retailer and having had a previous training on abattoir hygiene had a statistically significant relationship with the knowledge of good hygiene practice $(p<0.05)$. It was shown that a greater proportion of workers $(56.3 \%)$ who had good knowledge of hygiene practices were retailers.

Table 4. Relationship of socio-demographic and other variables with hygiene practices

\begin{tabular}{|c|c|c|c|c|c|}
\hline \multirow[t]{2}{*}{ Variable } & \multicolumn{5}{|c|}{$\begin{array}{c}\text { Practice about good hygiene } \\
n=188 \\
\mathrm{~N}(\%) \\
\end{array}$} \\
\hline & $\begin{array}{l}\text { Good } \\
(n=161)\end{array}$ & Poor $(n=27)$ & Total & $\chi^{2}$ & p-value \\
\hline \multicolumn{6}{|l|}{ Age group (years) } \\
\hline$\leq 30$ years & $92(57.1)$ & $13(48.1)$ & 105 & 0.759 & 0.384 \\
\hline$>30$ years & $69(42.9)$ & $14(51.9)$ & 83 & & \\
\hline \multicolumn{6}{|l|}{ Sex } \\
\hline Male & $120(74.5)$ & $16(59.3)$ & 136 & 2.696 & 0.101 \\
\hline Female & $41(25.5)$ & $11(40.7)$ & 52 & & \\
\hline \multicolumn{6}{|l|}{ Marital status } \\
\hline Married & $81(50.3)$ & $16(59.3)$ & 97 & 0.741 & 0.389 \\
\hline Not married & $80(49.7)$ & $11(40.7)$ & 91 & & \\
\hline \multicolumn{6}{|l|}{ Religion } \\
\hline Christianity & $144(89.4)$ & $24(88.9)$ & 168 & 0.007 & 0.931 \\
\hline Islam & $17(10.6)$ & $3(11.1)$ & 20 & & \\
\hline \multicolumn{6}{|l|}{ Level of education } \\
\hline$<$ Secondary education & $58(36.0)$ & $13(48.1)$ & 71 & 1.446 & 0.229 \\
\hline$\geq$ Secondary education & $103(64.0)$ & $14(51.9)$ & 117 & & \\
\hline \multicolumn{6}{|l|}{ Work experience (years) } \\
\hline$\leq 5$ years & $87(54.0)$ & $15(55.6)$ & 102 & 0.021 & 0.883 \\
\hline$>5$ years & $74(46.0)$ & $12(44.4)$ & 86 & & \\
\hline \multicolumn{6}{|l|}{ Category of worker } \\
\hline Retailer & $81(50.3)$ & $12(44.4)$ & 93 & 0.318 & 0.573 \\
\hline Others & $80(49.7)$ & $15(55.6)$ & 95 & & \\
\hline \multicolumn{6}{|c|}{ Previous training on abattoir work } \\
\hline No & $30(18.6)$ & $9(33.3)$ & 139 & 3.039 & 0.081 \\
\hline Yes & $131(81.4)$ & $18(66.7)$ & 49 & & \\
\hline \multicolumn{6}{|l|}{ Knowledge } \\
\hline Good & $130(80.7)$ & $12(44.4)$ & 142 & 16.487 & $<0.001 *$ \\
\hline Poor & $31(19.3)$ & $15(55.6)$ & 46 & & \\
\hline
\end{tabular}


Table 4 revealed the relationship between socio-demographic characteristics of the respondent and good hygiene practices. It shows that $130(80.7 \%)$ abattoir workers who had good hygiene practices also had good knowledge about good hygiene practices compared to only $9.3 \%$ who had poor knowledge. Only knowledge had statistically significant association with good abat- toir hygiene practices $(p<0.05)$. Good knowledge of good hygiene practices is the only statistically significant (AOR: 4.58; CI:1.8-11.7); $\mathrm{p}=0.001$ ) predictor of good abattoir hygiene practice (Table 5). Those that have good knowledge have 5 times higher odds of engaging in good hygiene practices compared to those with poor knowledge.

Table 5. Predictors of good hygiene practices

\begin{tabular}{|c|c|c|c|c|}
\hline \multirow[t]{2}{*}{ Independent Variables } & \multirow[t]{2}{*}{ AOR } & \multirow[t]{2}{*}{ p-value } & \multicolumn{2}{|c|}{ 95\% C.I for AOR } \\
\hline & & & Lower & Upper \\
\hline \multicolumn{5}{|l|}{ Sex } \\
\hline Male & 1.29 & 0.65 & 0.43 & 3.86 \\
\hline Female & 1 & & & \\
\hline \multicolumn{5}{|c|}{ Previous training on abattoir work } \\
\hline No & 0.60 & 0.37 & 0.19 & 1.83 \\
\hline Yes & 1 & & & \\
\hline \multicolumn{5}{|c|}{ Knowledge of good hygiene practices } \\
\hline Good & 4.58 & $0.001 *$ & 1.80 & 11.66 \\
\hline Poor & 1 & & & \\
\hline
\end{tabular}

Table 6. Availability of abattoir facilities

\begin{tabular}{lcc}
\hline Facility & Central meat market & SlaughterslabSlaughter slab \\
\hline Residential area & NA & NA \\
Local housing around abattoir & A & A \\
Lairage & NA & A \\
Slaughter hall & A & NA \\
Gut and tripe room & NA & NA \\
Detained meat room & NA & NA \\
Condemned meat room & A & NA \\
Offal room & NA & NA \\
Hide and skin room & NA & NA \\
Cutting room & NA & NA \\
Cold room & A & NA \\
Supply of hot and cold water under pressure & NA & NA \\
Veterinary inspection room & NA & NA \\
Disinfection facilities & NA & NA \\
Personnel welfare room & A & A \\
Veterinary office & A & NA \\
Cloak room & NA & NA \\
Facilities for condemned meat, offal or carcass disposal & NA & NA \\
Sufficient space for expansion & A & A \\
Freedom for flooding & A & A \\
Well & A & A \\
Tap & NA & NA \\
Borehole & A & A \\
Water closet & NA & NA \\
Pit latrine & NA & NA \\
\hline Key A A & & \\
\hline
\end{tabular}

Key: A=Available; $\mathrm{NA}=$ Not available 


\section{Discussion}

This study was designed to investigate the knowledge and hygiene practices and its determinants among workers in the abattoir and slaughter slab in Abakaliki, Ebonyi State and to assess the facilities. Although there was overall good knowledge and hygienic practices, some essential hygiene practices were poorly practised in our study (Table 2 refers). A poor level of practice of good hygiene has been described by studies across six towns in Southeast Nigeria ${ }^{20}$, in North Central Nigeria $^{15}$ and Kenya ${ }^{31}$. Interestingly, although $71.3 \%$ of our respondents knew that regular hand-washing was important (Table 1 refers), only $44.1 \%$ (Table 2) reportedly practised hand-washing before and after handling of meat. Since $71.8 \%$ (Table 2) reported washing hands after using the toilet, that may be what they consider adequate as regular hand-washing. The poor practice of hand-washing after handling of meat we found (Table 2 refers) is similar to studies in Oyo State, Nigeria ${ }^{17}$ where in $80 \%$ of the abattoir and slaughterhouses, there was poor practice and also in five North Central States in Nigeria $^{32}$ where only $6 \%$ practised regular hand-washing. In contrast, the practice of hand-washing after operations was much higher ( $98.3 \%$ of the workers) in the abattoir in the Abuja area of the Federal Capital Territory (FCT), Nigeria. ${ }^{33}$. Among these, observation of the practice was employed only in the study in Oyo State. Careful and frequent hand-washing is advocated to reduce contamination8. Unwashed hands from poor personal hygiene may transmit microorganisms to wellcleaned surfaces before processing begins 8 thus contaminating the meat while on the other hand, workers with poor hand-washing practices are at risk of getting infected with zoonoses ${ }^{34}$. A possible explanation for why less than half used soap and water to clean their work surfaces may be a knowledge gap in that area.

Overall, 75.5\% had good knowledge of good hygiene practices and PPE in contrast to a study in Kwara state where $18 \%$ had good knowledge of food safety risks ${ }^{35}$. The percentage of workers in abattoir who wore aprons/overalls- (which was the commonest PPE used in our study)- in studies in Abuja FCT, Nigeria ${ }^{33}$ and Ethiopia9 was considerably higher $(69.2 \%$ and $92.3 \%$ respectively) than the $54 \%$ of workers who wore PPE in our study. Lower percentages were reported by studies in Oyo State17 (32\%), Kwara State35 (32.6\%) and Kaduna State ${ }^{36}(18.2 \%)$ and five North Central States all in Nigeria ${ }^{32}(27.8 \%)$. Although the study in Abuja was self-reporting, their higher rates of PPE use and hand-washing after operations may be due to the re- ported attendance of public health education programs on abattoir operations by $54.2 \%$ of the workers. The overwhelmingly common practice of open dumping by the respondents appears to be a systemic problem of poor waste management practices in Nigeria ${ }^{37,38}$. Expectedly, the majority $(81.3 \%)$ of the abattoir workers reported the apron as the most common PPE used, though this was much higher than was found in Southeast and North Central Nigeria ${ }^{15,35}$. In one of the studies in North central Nigeria ${ }^{35}$, safety boots was the most commonly used PPE. Protective clothing protects the meat from contamination and the workers from zoonoses.

The predictor of good hygiene practice being good knowledge accords with the observation by Alhaji and Baiwa ${ }^{15}$ which showed that workers who knew the correct definition of slaughterhouse hygiene were less likely to demonstrate poor preventive practices but differs from those of Junaidu ${ }^{39}$ where the predictor of good hygiene practice among the abattoir workers was a positive attitude not good knowledge. Our finding of previous training being significantly associated with good hygiene practice is similar to that of a study in Kenya where longer years of experience and increased capacity through training were significantly associated with good hygiene practices ${ }^{40}$. Training is expected to improve knowledge and practice when done adequately and other factors are in place. Only the Central meat market had available cold rooms and this may account for why the practice of storing meat in the cold room was not universal. The two cold rooms were not in the abattoir but adjoining streets and owned by individuals. The government has however built a cold room and other infrastructure in the Central meat market after this study soon to be commissioned, justifying the perception by a good majority of the respondents that the government is actively involved in ensuring good hygiene practice in the abattoir. The positive results of knowledge and hygiene practices may be attributed to the daily inspection of the slaughterhouses by officials of the Ministry of Health and Ministry of Environment as regulatory agencies and the occasional health talks given as $70.2 \%$ of them asserted government involvement in ensuring good hygiene practices. However, it is noted that observation of the workers is needed to confirm the reports of good hygiene practices. Good personal hygiene, other hygiene practices and standard facilities are all necessary for avoidance of contamination by microorganisms and transmission of zoonoses. The gaps we have identified in knowledge and practice, 
provide evidence for use in the design of intervention programmes for this group of workers.

\section{Conclusion}

There is an overall good knowledge of hygiene practices as well as appreciably good hygiene practices possibly due to the health talks by the supervisory ministry officials. However, serious gaps in practice by more than half of the respondents were noted in some essential practices. The determinant of good hygienic practice was a good knowledge of hygienic practices. Notwithstanding the limitation from the self-reporting bias, this work contributes to our understanding of the knowledge and practice of hygienic practices with its determinants among workers in the abattoir and slaughter slab in Abakaliki and the practical implication suggests a basis for the immediate implementation of targeted interventions by government and stakeholders starting with training on the importance of good hygiene and sanitation. We recommend that a policy priority among policy-makers in the state be, developing and ensuring the implementation of policies that will safeguard our meat from contamination and protect the abattoir workers from zoonoses.

\section{Disclosure of conflict of interests}

All authors declare no conflict of interest with regards to this manuscript.

\section{References}

1. FAO-OIE-WHO. Contributing to One World, One Health. A Strategic Framework for Reducing Risks of Infectious Diseases at the Animal-Human-Ecosystems Interface. 2008. p. 1-68.

2. OIE Working Group. Control of hazards of public health and animal health importance through ante- and post- mortem meat inspection. 1999. p. 1-20.

3. Ducrotoy MJ, Bertu WJ, Ocholi RA, Gusi AM, Bryssinckx W, Welburn S, et al. Brucellosis as an Emerging Threat in Developing Economies: Lessons from Nigeria. PLoS Negl Trop Dis. 2014;8(7):1-18.

4. Jacxsens L, Kussaga J, Luning PA, Spiegel M Van Der, Devlieghere F, Uyttendaele M. A Microbial Assessment Scheme to measure microbial performance of Food Safety Management Systems. Int J Food Microbiol. 2009;134(1-2):113-25.

5. Govender R. A hazard analysis methodology for the South African abattoir hygiene management system. $\mathrm{Br}$ Food J. 2015;116(February).

6. Akinnibosun F, Imade O. Hygiene Assessment of the Performance of Food Safety Management System
Implemented by Abattoirs in Edo State, Nigeria. I Appl Sci Environ Manag. 2015;19(3):521.

7. Grace D, Olowoye J, Dipeolu M, Odebode S, Randolph T. The influence of gender and group membership on food safety: The case of meat sellers in Bodija market, Ibadan, Nigeria. Trop Anim Health Prod. 2012;44(SUPPL.1):53-9.

8. Food and Agricultural Organization. Abattoir Development: Options and Designs for Hygienic Basic and Medium-Sized Abattoirs. 2008.

9. Haileselassie M, Taddele H, Adhana K, Kalayou S. Food safety knowledge and practices of abattoir and butchery shops and the microbial profile of meat in Mekelle City, Ethiopia. Asian Pac J Trop Biomed. 2013;3(5):407-12.

10. Iroha IR, Ugbo EC, Ilang DC, Oji AE, Ayogu TE. Bacteria contamination of raw meat sold in Abakaliki, Ebonyi State Nigeria. J Public Heal Epidemiol. 2011;3(2):49-53.

11. Fasanmi OG, Ayodeji IO, Oloso NO, Fasina FO. Retrospective studies of abattoir zoonoses in Nigeria: public health implications. CAB Rev Perspect Agric Vet Sci Nutr Nat Resour. 2017;12(January):1-14.

12. Ngbede EO, Raji MA, Kwanashie CN, Okolocha EC, Gugong VT, Hambolu SE. Serological prevalence of leptospirosis in cattle slaughtered in the Zango abattoir in Zaria, Kaduna State, Nigeria. Vet Ital. 2012;48(2):179-84.

13. Allwin B, Kalaignan PA, Senthil NR. Abattoir characteristics and seroprevalence of bovine brucellosis in cattle slaughtered at Bodija Municipal Abattoir, Ibadan, Nigeria. J Vet Med Anim Heal. 2015;7(5):169-72.

14. Adesokan HK, Sulaimon MA. Poor Slaughterhouse Waste Management: Empirical Evidences from Nigeria and Implications on Achieving Millennium Development Goals. Int J Sci Technol. 2014;3(6):110-27.

15. Alhaji NB, Baiwa M. Factors affecting workers' delivery of good hygienic and sanitary operations in slaughterhouses in north-central Nigeria. Sokoto J Vet Sci. 2015;13(1):29-37.

16. Olowoporoku OA. Assessing Environmental Sanitation Practices in Slaughterhouses in Osogbo, Nigeria: Taking the Good with the Bad. MAYFEB J Environ Sci. 2016;1:44-54 PubMed .

17. Fasanmi OG, Makinde GEO, Popoola MA, Fasina OF, Matere J, Kehinde O, et al. Potential risk factors associated with carcass contamination in slaughterhouse operations and hygiene in Oyo state, Nigeria. Int J Livest Prod. 2018;9(August):211-20.

18. Adesokan HK, Akinseye VO, Sulaimon MA. Knowledge and practices about zoonotic tuberculosis 
prevention and associated determinants amongst livestock workers in Nigeria; 2015. PLoS One. 2018;13(6):1 PubMed -12.

19. Douglas KE, Ovua A, Orji C, Sapira B. Health Implications of Sanitation in a Public Abattoir in Port Harcourt, Nigeria. Niger Heal J. 2013;13(2):91 PubMed -5 .

20. Azuamah Y, Amadi AN. Distribution of Bacterial Isolates from Contact Surfaces of Meat Handlers in Abattoirs of Southeastern, Nigeria. Int J Res. 2019;06(07):109 PubMed -19.

21. Federal Ministry of Environment. Policy Guidelines on Sanitary Inspection of Premises. Abuja, Nigeria; 2005. p. 9-10.

22. Chika E, Ifeanyichukwu I, Malachy U, Benigna O, Adaora EC, Olisa A, et al. Phenotypic detection of AmpC enzymes and antimicrobial susceptibility of Klebsiella spp. isolated from abattoir. Int J Appl Microbiol Biotechnol Res. 2016;4:117-21.

23. Onuoha SC, Eluu SC, Okata MO. In-vitro Antimicrobial Resistance of Shigella and Salmonella species Recovered from Abattoir effluent in Afikpo, South Eastern Nigeria. Int J Curr Microbiol Appl Sci. 2016;5(4):488-97.

24. Ayogu TE, Orji JO, Nwojiji EC, Umezurike RC, Ibiam UU. Antibiotic Susceptibility Pattern of Salmonella and Pseudomonas Species Isolated from Meat Market and Ogoja Road Abattoir Effluents in Abakaliki Metropolis. World J Med Sci. 2018;15(1):34 PubMed -47.

25. Kalu NK, Sowechi E, Anuonye BC. Prevalence of intestinal helminthes in ruminants slaughtered at Abakaliki abattoir, Ebonyi State, Nigeria. J Anim Sci Vet Med. 2018;3(3):58-64.

26. National Bureau of Statistics. Annual abstract of statistics, 2012. National Bureau of Statistics, Federal Republic of Nigeria. 2012. p. 1-602.

27. Wheather Spark (Internet). Average Weather in Abakaliki Nigeria.

28. International Livestock Research Institute. Assessment of risks to human health associated with meat from different value chains in Nigeria: using the example of the beef value chain. 2011.

29. Jianu C, Golet I. Knowledge of food safety and hygiene and personal hygiene practices among meat handlers operating in western Romania. Food Control. 2014;42:214-9 PubMed .
30. Varadheswari T, Dandekar RH, Sharanya T. A Study on the Prevalence and KAP Regarding Cervical Cancer Among Women Attending a Tertiary Care Hospital in Perambalur. Int J Prev Med Res. 2015;1(3):71 PubMed -8. 31. Cook EAJ, De Glanville WA, Thomas LF, Kariuki $\mathrm{S}$, Bronsvoort BM de C, Fèvre EM. Working conditions and public health risks in slaughterhouses in western Kenya. BMC Public Health. 2017;17(1):1 PubMed -12.

32. Abiayi EA, Inabo HI, Jatau ED, Makinde AA, Sar TT, Ugbe DA, et al. Knowledge, attitudes, risk factors and practices (KARP) that favor leptospira infection among abattoir workers in North Central Nigeria. Asian J Epidemiol. 2015;8(4):104 PubMed -13.

33. Adeolu, A.T., Opasola, A.O., Salami, O.O., Iyanda, A.Y., and Omenta RC. Sanitary Status and Compliance with the Standard Slaughter Practices in Karu Abattoir Abuja Municipal Area Council of the FCT, Nigeria. Int J Curr Innov Adv Res. 2019;2(2):1-14.

34. Brown PD, McKenzie M, Pinnock M, McGrowder D. Environmental risk factors associated with leptospirosis among butchers and their associates in Jamaica. Int J Occup Environ Med. 2011;2(1):47-57.

35. Odetokun IA, Ghali-Mohammed I, Alhaji NB, Nuhu AA, Oyedele HA, Ameen SA, et al. Occupational Health and Food Safety Risks in Ilorin, Northcentral Nigeria: A Cross-sectional Survey of Slaughterhouse Workers. Food Prot Trends. 2020;40(4):241 PubMed -50. 36. Richard O, Okolocha E, Odinya A, Paul M, Audu D, Adamu D. Public Health Risk of Abattoir Operation in Zango Abattoir Zaria, Kaduna State Nigeria. Annu Res Rev Biol. 2015;5(2):139-46.

37. Omole DO, Isiorho SA, Ndambuki JM. Waste management practices in Nigeria: Impacts and mitigation. Spec Pap Geol Soc Am. 2016;520(33):377-86.

38. Ike CC, Ezeibe CC, Anijiofor SC, Nik Daud NN. Solid waste management in Nigeria: Problems, prospects, and policies. J Solid Waste Technol Manag. 2018;44(2):163-72.

39. Junaidu YM, Bhagavandas M, Umar Y. Study of Knowledge, Attitude and Practices Regarding Hygiene among Abattoir Workers in Kano State Metropolitan, Nigeria. Int J Sci Res. 2015;4(1):2474-8.

40. Wambui J, Karuri E, Lamuka P, Matofari J. Good hygiene practices among meat handlers in small and medium enterprise slaughterhouses in Kenya. Vol. 81, Food Control. 2017. p. 34-9. 